\title{
Laparoscopic diaphragmatic hernioplasty in a dog
}

\section{Hernioplastia diafragmática laparoscópica em cão}

\section{João Pedro Scussel FERANTI ${ }^{1}$; Marília Teresa de OLIVEIRA $^{1}$; Hellen Fialho HARTMANN ${ }^{1}$; Luis Felipe Dutra CORRÊA $^{1}$; Saulo Tadeu Lemos PINTO FILHO ${ }^{1}$; Marcella Teixeira LINHARES ${ }^{1}$; Rafael Oliveira CHAVES ${ }^{1}$; Marco Augusto Machado SILVA ${ }^{2}$; Maurício Veloso BRUN ${ }^{1}$}

\author{
${ }^{1}$ Universidade Federal de Santa Maria, Faculdade de Medicina Veterinária, Centro de Ciências Rurais, Departamento de Clínica de Pequenos \\ Animais, Santa Maria - RS, Brazil \\ ${ }^{2}$ Universidade de Passo Fundo (UPF), Faculdade de Agronomia e Medicina Veterinária, Departamento de Pequenos Animais, Passo Fundo \\ - RS, Brazil
}

\begin{abstract}
A diaphragmatic hernia is characterized by the passage of the abdominal viscera into the thoracic cavity, which may be congenital or acquired. Its treatment is achieved by surgical correction. When there is no tissue or in cases of herniation with a chronic disease, the use biological or synthetic implants is recommended. The objective of this study was to report a technique of laparoscopic diaphragmatic hernia repair using bovine pericardium preserved in a canine, using three portal accesses. Due to the large diaphragmatic defect, reduction with the aid of a network of preserved bovine pericardium in formaldehyde $4 \%$ was chosen. The mesh was sutured to the transversus abdominus muscle in two layers. The first layer was sutured using simple continuous pattern, and the second one using simple interrupted sutures. The patient collapsed and died 24 hours postoperatively. However, the purposed technique was feasible.
\end{abstract}

Keywords: Conserved membrane. Implant. Laparoscopic. Surgery.

\section{Resumo}

A hérnia diafragmática é caracterizada pela passagem das vísceras abdominais para a cavidade torácica, podendo ser de origem congênita ou adquirida, que exige o tratamento cirúrgico. Quando houver ausência de tecido ou em casos de herniação com evolução crônica, recomenda-se a utilização de implantes biológicos ou sintéticos. O objetivo deste trabalho é relatar a técnica de herniorrafia diafragmática laparoscópica com o uso de pericárdio bovino conservado em um canino, a partir do acesso laparoscópico com três portais. Devido ao grande defeito diafragmático, optou-se pela sua redução com o auxílio de implante de pericárdio bovino conservado em formaldeído a $4 \%$, este fixado a musculatura diafragmática com sutura intracorpórea, utilizando para isso duas camadas de sutura ambas com náilon 0 , a primeira contínua simples seguida de pontos isolados simples, em toda extensão da membrana conservada. Apesar do animal vir a óbito nas primeiras 24 horas do pós-operatório, a técnica adotada se mostrou viável.

Palavras-chave: Membrana conservada. Implante. Laparoscopia. Cirurgia.

Diaphragmatic hernia is the passage of abdominal viscera into the thoracic cavity through following rupture of the diaphragm muscle. Diaphragmatic defects may occur due to congenital malformation or acquired/traumatic causes (MAZZANTI et al., 2003). The treatment of choice is surgical reduction, especially due to the role of anatomical concerns on its physiopathology.
Correspondence to:

João Pedro Scussel Feranti

Universidade Federal de Santa Maria, Hospital Veterinário Av. Roraima, 1000

CEP 97105-230, Santa Maria, Rio Grande do Sul, Brazil e-mail: johny.sf@hotmail.com

Received: $23 / 03 / 2015$

Approved: 26/02/2016 
The use of biologic or synthetic implants is recommended in cases of absence of tissue margins for proper reduction of the defect with sutures or in chronic hernias, as first intention closure may cause intraoperative rupture or early postoperative dehiscence, due to high tension of the sutures.

Other researchers have reported the use of several techniques of laparoscopic approach for diaphragmatic hernioplasty in human patients, small animals and large animals, both in the clinical setting or experimentally (BECK et al., 2004; KROHN et al., 2012; PARELKAR et al., 2012; RÖCKEN et al., 2013). However, laparoscopic hernia repairement using biologic meshes such as bovine pericardium has not been reported. Thus, it should be tested in order to determine its feasibility, benefits and limitations.

The aim of the current study was to report the first attempt of laparoscopic diaphragmatic hernia repair using bovine pericardium preserved in glycerol in a dog presenting a complicated wide-margins chronic diaphragmatic defect.

A two-year-old female Dachshund, with $6.2 \mathrm{~kg}$ of body weight was admitted due to inappetite for several days. The dog had a car accident two months prior. Findings on physical exam were abdominal pain, dyspnea and intestinal peristalsis sounds on thoracic auscultation.

Hemogram, basic serum biochemical assays, as well as ventrodorsal and laterolateral thoracoabdominal radiographs were requested. Radiographic imaging revealed intestinal loops within the thoracic cavity, which confirmed the diagnosis of diaphragmatic hernia. The patient was prepared for laparoscopic approach for reduction of the diaphragmatic defect.

Premedication included midazolam $(0.2 \mathrm{mg} \mathrm{kg})$ and morphine sulphate $(0.4 \mathrm{mg} \mathrm{kg})$. Anesthesia was induced following a bolus of diazepam $(0.5 \mathrm{mg} \mathrm{kg})$ and propofol (4 $\mathrm{mg} \mathrm{kg}$ ) and maintained using isoflurane vaporized in $100 \%$ oxygen in a semi-open circuit. Mean arterial pressure (PAM) was maintained between 60 and $150 \mathrm{mmHg}$ during the procedure.
Dopamine constant rate infusion $(10 \mu \mathrm{g} / \mathrm{kg} / \mathrm{min})$ would be used if PAM reached bellow $60 \mathrm{mmHg}$ and Fentanyl constant rate infusion $(15 \mu \mathrm{g} / \mathrm{kg} / \mathrm{h})$, following initial IV bolus ( $2.5 \mu \mathrm{g} \mathrm{kg})$, if PAM reached $150 \mathrm{mmHg}$.

The animal was placed in dorsal recumbence and following surgical field preparation, a $10-\mathrm{mm}$ trocar was inserted into the abdomen, using the open technique, through a median mini-celiotomy at the midpoint between the umbilicus and the pubis. Pneumoperitoneum was established using $\mathrm{CO}_{2}$ at 12 $\mathrm{mmHg}$. Two additional instrument ports were placed using the triangulation principle, on the left $(10-\mathrm{mm}$ trocar) and on the right side (5-mm trocar).

Following initial inspection using a $10-\mathrm{mm} 0^{\circ}$ telescope, a wide-margin diaphragmatic defect was seen (Figure 1). The herniated tissues, which included bowel loops, pancreas, spleen, omentum and liver, were grasped and reduced into the abdominal cavity using Kelly and Babcock forceps. Herniorrhaphy was begun using interrupted horizontal mattress sutures with 0 UPS nylon thread, taking bites on the median margins of the defect on both sides. However, it was not possible to perform complete apposition of the defect margins due to high tension. Extra sutures were performed in order to reduce tension, but complete closure of the defect was not possible. Thus, mesh hernioplasty was opted. A bovine pericardium mesh preserved in formaldehyde $4 \%$ solution (HP Biopróteses, Brazil) was inserted through the $10-\mathrm{mm}$ port. The mesh was sutured to the transversus abdominus muscle in two layers using 0 USP nylon thread. The first layer was sutured using simple continuous pattern and the second layer, using simple interrupted sutures, in order to enhance overlapping of the implant obvert the diaphragmatic defect. Pulmonary progressive re-expansion was performed by the anesthetist during the finalization of the last interrupted suture, in order to minimize pneumothorax. The trocars were withdrawn from the abdominal wall, pneumoperitoneum was drained and wounds were closed routinely. Residual 
pneumothorax was drained following surgery by thoracocentesis.

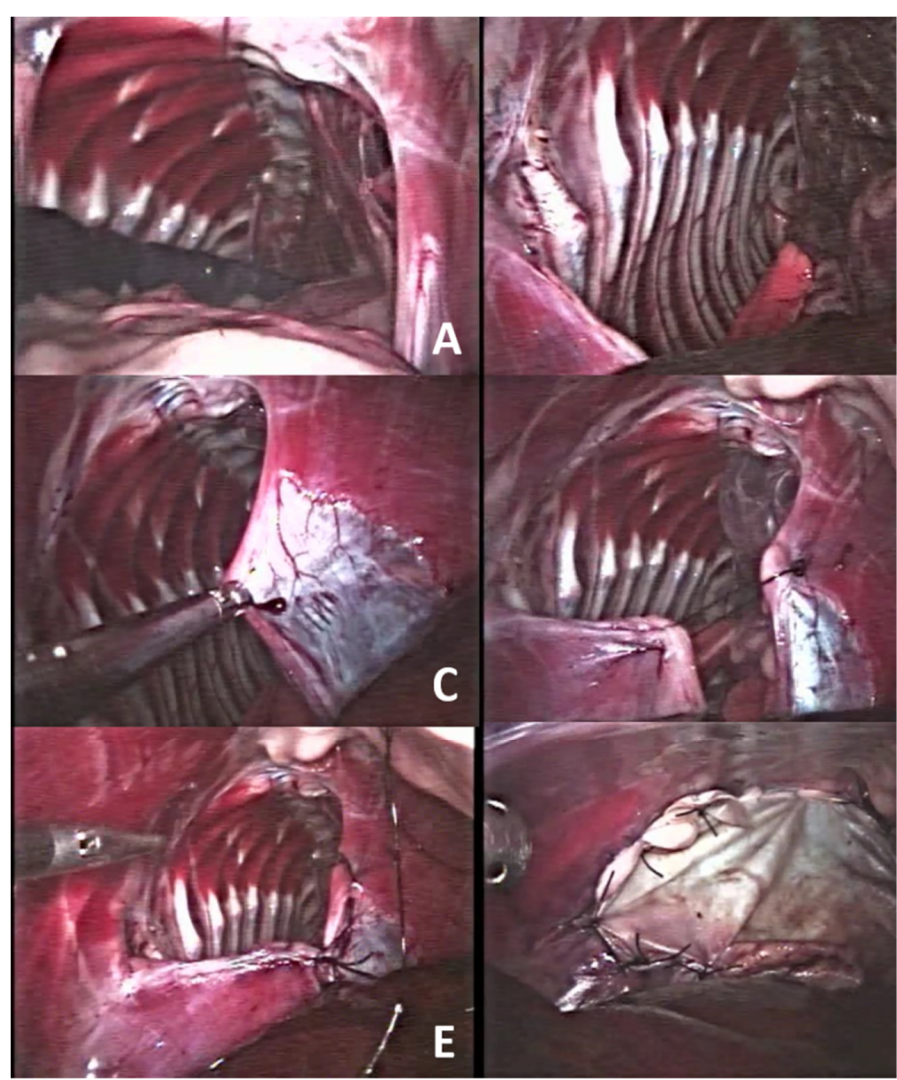

Figure 1 - Intraoperative images of the laparoscopic implantation of bovine preserved pericardium mesh for diaphragmatic hernia repair in a Dachshund bitch. A) Wide diaphragmatic defect, showing spleen, intestines, omentum, liver lobes and gallbladder. B) Diaphragmatic hernia following retrieval of the herniated content. C) Attempt of approximation of the margins of the defect using grasping forceps. D) Attempt of reduction of the defect using simple interrupted sutures using nylon 0 USP. E) Diaphragmatic hernioplasty at the dorsal aspect using nylon 0 USP, interrupted horizontal mattress pattern. F) Attachment of the bovine preserved pericardium to the diaphragm muscle using nylon 0 USP in two layers: simple continuous pattern followed by simple interrupted sutures.

Following 24 hours of postoperative intensive care, the patient had a sudden cardiorespiratory. arrest, which did not react to the resuscitation intervention. Necropsy was not allowed by the owners and the exact causa mortis was not determined.

Laparoscopic access provides exploration of both abdominal and thoracic cavities in patients with diaphragmatic defects, which is an important advantage against the open explorative approach (BECK et al., 2004). In the patient of the current report, inspection of the abdomen and thorax was carried out and details such as adhesions among the viscera and confirmation of the diaphragmatic defect were viewed. Such benefits corroborate other studies that mentioned the effectiveness of laparoscopy as a simultaneous diagnostic and therapeutic tool (RÖCKEN et al., 2013).

Due to the lack of scientific evidence regarding the laparoscopic approach for diaphragmatic hernioplasty using bovine preserved pericardium graft, further studies are required in order to assess the effectiveness of such technique. A study assessed the use of bovine pericardium preserved in hypertonic sugar solution for diaphragmatic hernia repair in dogs (MAZZANTI et al., 2003). On the 9th month of follow-up, the diaphragmatic defect was repaired and a fibrous membrane was present on the defect site. Moreover, there were no evidences of infection nor rejection on the implant site.

The current study proposes the use of other type of preserved pericardium and other minimally invasive reconstructive technique, which proved to be feasible in dogs. Nevertheless, such hypothesis should be tested and before wide use in the routine setting. Moreover, long-term assessment is necessary so that laparoscopic graft implantation could be considered as a potential alternative for diaphragmatic hernia repair in dogs. 


\section{References}

BECK, C. A. C.; PIPPI, N. L.; BRUN, M. V.; CONTESINI, E. A.; CUNHA, A. F.; STEDILE, R.; BONFADA, A. T.; FILHO, A. P. F. S.; VIEIRA JUNIOR, A. R. P. V.; SILVA, T. F.; BORDIN, A. I. Laparoscopia nas hérnias diafragmáticas: estudo experimental em cães. Ciência Rural, v. 34, n. 6, p. 1849-1855, 2004. doi: http://dx.doi.org/10.1590/S010384782004000600028

KROHN, J.; BÖHM, J.; ENNEN, S.; GERHOLD, H. W.; WEHREND, A. Erfolgreiche chirurgische Therapie einer angeborenen Zwerchfellhernie bei einem vier Tage alten Trakehner-Fohlen. Pferdeheilkunde, v. 28, n. 2, p. 167170, 2012.

MAZZANTI, A.; RAISER, A. G.; PIPPI, N. L.; ALVES, A. S.; FARIA, R. X.; ALIEVI, M. M.; BRAGA, F. A.; SALBEGO, F. Z. Hernioplastia diafragmática em cão com pericárdio bovino conservado em solução supersaturada de açúcar. Arquivo Brasileiro de Medicina Veterinária e Zootecnia, v. 55, n. 6, p. 677-684, 2003. doi: http://dx.doi.org/10.1590/S0102-09352003000600005.
PARELKAR, S. V.; OAK, S. N.; PATEL, J. L.; SANGHVI, B. V.; JOSHI, P. B.; SAHOO, S. K.; SAMPAT, N. Traumatic diaphragmatic hernia: management by video assisted thoracoscopic repair. Journal of Indian Association of Pediatric Surgeons, v. 17, n. 4, p. 180-183, 2012. doi: http://dx.doi.org/10.4103/0971-9261.102345.

RÖCKEN, M.; MOSEL, G.; BARSKE, K.; WITTE, T. S. Thoracoscopic diaphragmatic hernia repair in a warmblood mare. Veterinary Surgery, v. 42, n. 5, p. 591594, 2013. doi: http://dx.doi.org/10.1111/j.1532950X.2013.12009.x. 